\title{
Immunoreactive human growth hormone like peptides in tropical Penaeids and the effect of dietary hGH on Penaeus vannamei larval development
}

\author{
$\bigcup_{\text {Jean-Yves Toullec }}^{(1) *}$, Gilles Le Moullac ${ }^{(2)}$, Gérard Cuzon ${ }^{(2)}$ and Alain Van Wormhoudt ${ }^{(1)}$ \\ (1) Laboratoire de Biologie Marine du Collège de France, BP 38, 29182 Concarneau, France. \\ * Present address: Laboratoire de Biochimie et Physiologie du Développement, \\ CNRS-URA 686, Ecole Normale Supérieure, 46 rue d'Ulm, 75230 Paris Cedex 05, France. \\ (2) Aquacop, IFREMER, Centre Océanologique du Pacifique, Taravao vairao, Tahiti, Polynésie Française.
}

Received Scptember 7, 1990; accepted January 15, 1991.

Toullec J.-Y., G. Le Moullac, G. Cuzon, A. Van Wormhoudt. Aquat. Living Resour., 1991, 4, 125-132.

\begin{abstract}
Human growth hormone like peptides were present in Penaeus indicus as two molecular forms: one with a molecular weight about $25 \mathrm{kDa}$ which is similar to that of the vertebrate growth hormonc and a smaller form of $2 \mathrm{kDa}$. Quantitative variations of hGH-like peptides in different larval stages of threc spccies of Penaeids (Penaeus vannamei, $P$. stylirostris, $P$. indicus) suggest a possible involvement of hGH-like peptides in the development. Human growth hormone (hGH) supplementation in the diet of Penaeus vannamei larvae seems to have a positive effect on the size and on the quality of the animals estimated by their resistance to salinity stress.
\end{abstract}

Keywords : Penacids ( $P$. vannamei, P. stylirostris, $P$. indicus), growth, growth hormone.

Peptides immunoréactifs apparentés à l'hormone de croissance humaine chez les Pénéides tropicaux et effet d'un apport alimentaire d'hGH sur le développement larvaire de Penacus vannamei.

Résumé

Deux types de peptides apparentés à l'hormone de croissance humaine ont été mis en évidence chez Penaeus indicus: le premier a une masse moléculaire d'environ $25 \mathrm{kDa}$ qui est comparable à celle de l'hormone de croissance de vertébré et le second est caractérisé par une masse moléculaire plus petite de l'ordre de $2 \mathrm{kDa}$. Les variations quantitatives des peptides apparentés à l'hormone de croissance de vertébré à différents stades larvaires de trois espèces de Pénéides ( $P$. vannamei, P. stylirostris, $P$. indicus) suggèrent une possible implication de l'hormone de croissance apparentéc dans le développement. L'addition d'hormone de croissance humaine dans le régime alimentaire de larves de Penaeus vannamei semble avoir un effet positif sur la taille et sur la qualité des animaux. Cettc dernière est estimée au moyen d'un test de résistance à des chocs de salinité.

Mots-clés : Pénéides ( $P$. vannamei, $P$. stylirostris, $P$. indicus), croissance, hormone de croissance.

\section{INTRODUCTION}

The improvement of immunological techniques has allowed the detection of numerous peptides related to vertebrate molecules, mainly in the nervous system and the gut of many invertebrate and protochordate species (Fritsch et al., 1982; Thorndyke and Dockray, 1986) as well as unicellular organisms 
(Le Roith et al., 1980, 1981, 1982; Berelowitz et al., 1982).

A molecule related to insulin has been identified in intestinal tissue of molluscs (Plisetskaya et al., 1978) and insects (Duve and Thorpe, 1979; Moreau et al., 1981). Somatostatin-like peptide has been detected in nervous tissue of protochordates (Falkmer et al., 1977) and a few mollusc species (Schot et al., 1981; Grimm-J $\phi$ rgensen, $1983 a, b$; Assaka et al., 1987).

In crustaceans, as in other invertebrates, many peptides related to vertebrate hormones have been detected (Gastrin/CCK: Scalise et al., 1984; Favrel et al., 1987. Insulin: Sanders, $1983 a, b, c$. Calcitonin: Arlot-Bonnemains et al., 1986; Fouchereau-Péron et al., 1987. Neurophysin and vasopressin: Van Herp and Bellon-Humbert, 1982).

But the existence of such molecules does not address their biological function(s). The preservation of biological function depends on the conservation of the active site of the peptide and of its receptors. Although this preservation is necessary, it is not a good enough criterion. A similar molecule, even if its homology with the vertebrate molecule is significant, may have a different function (or no function) in the invertebrate and such a peptide may have different activities in different animals: (1) the function may be conserved (Joose, 1984), (2) partly conserved (Sanders, 1983c; Neushul, 1985; Duve et al., 1979; Tager et al., 1976; Arpagaus, 1987), (3) or different (Feurle et al., 1983; Grimm-J $\phi$ rgensen, 1983).

Morse (1984) has shown that the injection of vertebrate growth hormone in to young abalones increased their growth. Kawauchi (1986) confirmed these results using salmon growth hormone. Recently, Charmantier et al. (1989) showed that the injection of human growth hormone increased the growth of Homarus americanus larvae. If vertebrate hormones can increase the development of invertebrates, it is conceivable that endogenous molecules may exist. A homologous growth hormone might be more effective than a hormone from humans. On the basis that a common biological function may be related to a similar structure, we searched for an immunologically related substance in decapod crustaceans using antibody directed against human growth hormone (hGH). We have shown that human growth hormone-like peptides are present in the prawn Palaemon serratus in different tissues such as hepatopancreas, stomach and haemolymph (Toullec and Van Wormhoudt, 1987). The existence of hGH-like peptides leads to investigation of the function of the molecule. A first approach to understand the possible role of the immunoreactive peptide(s) (without isolation) in growth is to correlate the variations of this (these) molecule(s) with developmental parameters. Such an approach has been used in Palaemon serratus during the intermolt cycle which is necessarily involved in growth of arthropods (Toullec and Van Wormhoudt, 1987).
In the present work, our first purpose was to measure and characterize $\mathrm{GH}$-like molecules during another stage of development in crustaceans, the larval development and, in a second experiment, to determine if hGH was effective in crustaceans. These experimentions were in animals with economic value, the penaeid shrimps.

\section{MATERIAL AND METHODS}

\section{Animals}

Experiments have been made on three species of Penaeid larvae (P.vannamei, $P$. indicus and P. stylirostris) from the IFREMER station in Tahiti (Aquacop, 1983).

\section{Extraction}

hGH-like peptides were extracted from freeze-dried larvae with $0.1 \mathrm{M}$ ammonium acetate, $\mathrm{pH} 5.5$ in the proportion of $1 \mathrm{~g} \mathrm{d.w} .100 \mathrm{ml}$. The extracts were stored for $16 \mathrm{~h}$ at $4^{\circ} \mathrm{C}$, then centrifuged at $9000 \mathrm{~g}$ for $4 \mathrm{~min}$.

\section{Molecular sieving}

An extract of Mysis I of $P$. indicus was separated using a gel permeation chromatography with a G50 SF Sephadex column (Pharmacia) $(0.6 \times 140 \mathrm{~cm})$ which was previously equilibrated with ammonium acetate buffer. The column was calibrated with albumin $(67 \mathrm{kDa})$, RNase $(13 \mathrm{kDa})$, insulin $(5.7 \mathrm{kDa})$, glucagon (3550 Da), bacitracin (1411 Da) and RPCH (Red Pigment Concentrating Hormone) (1000 Da).

\section{Radioimmunoassay (RIA)}

Assays were made using commercial kits (CIS, ORIS Industrie, ref. SB-HGH). The antiserum was directed to $\mathrm{hGH}$ but the specificity against the other GHs was unknown. Animals used to study the variations of hGH-like peptides during larval stages had a diet without hormonal supplementation. The cross reactivity is $0.1 \%$ with human prolactin and $0.01 \%$ against $\mathrm{LH}$ and TSH.

\section{Proteins assay}

Protein measurement was estimated using the Lowry et al. (1951) method on shrimp extracts.

\section{Diets} Ltd.

Pure recombinant hGH was a gift from Sanoli,

hGH supplementation was realized on $P$. vannamei using alginate as ligand at low temperature $(0.1 \mathrm{mg} / 1$ of hGH was added to Précal mixture). The constituents of Précal are powders of fishes, molluscs and crustaceans with $50 \%$ of proteins, $11 \%$ of lipids and a humidity of $5 \%$. hGH was added as complement 
of the algae and the artemia (Artemia salina) with micropellets during rearing. Experiments were performed in triplicate with a density of 150 nauplii per tank.

The diets were:

Diet $1:$ algae + artemia

Diet 2 : algae + artemia + Précal

Diet 3 : algae + artemia + Précal + hGH

Algae proportion was constitued of:

- Isochrysis (Zoea ${ }_{1}$ to Zoea ${ }_{2}$ )

- Chaetoceros $\left(\right.$ Zoea $_{2}$ to Mysis $_{1}$ )

- Tetraselmis (Zoea ${ }_{2}$ to Mysis $_{1}$ )

The artemias were distributed as (artemii/stage/tank):

\begin{tabular}{cccccccc}
\hline Zoea & \multicolumn{3}{c}{ Mysis } & \multicolumn{4}{c}{ Post-larvae stages } \\
\hline$Z_{3}$ & $\mathbf{M}_{1}$ & $\mathbf{M}_{\mathbf{2}}$ & $\mathbf{M}_{\mathbf{3}}$ & $\mathbf{P}_{\mathbf{1}}$ & $\mathbf{P}_{\mathbf{2}}$ & $\mathbf{P}_{\mathbf{3}}$ & $\mathbf{P}_{\mathbf{4}}$ \\
\hline 5 & 10 & 20 & 25 & 35 & 45 & 75 & 110 \\
\hline
\end{tabular}

The "Précal" mixture was expressed in $\mathrm{g} / \mathrm{stage} /$ tank:

\begin{tabular}{cccccccc}
\hline Nauplii & & Zoea & & & Mysis & & $\begin{array}{c}\text { Post- } \\
\text { larvae }\end{array}$ \\
\hline $\mathrm{N}_{6}$ & $\mathrm{Z}_{1}$ & $\mathrm{Z}_{2}$ & $\mathrm{Z}_{3}$ & $\mathrm{M}_{1}$ & $\mathrm{M}_{2}$ & $\mathrm{M}_{3}$ & $\mathrm{P}_{1}$ \\
\hline 0.15 & 0.64 & 1.00 & 1.20 & 1.32 & 1.32 & 1.32 & 1.3 \\
\hline
\end{tabular}

\section{Biometry}

10 animals per stage and per tank were measured. The length of the larvae was the distance between the rostral base to the telson extremity.

\section{Larval quality}

Post larvae resistance was tested with five different salinities $(35,25,20,15,10 \%)$ during two hours (100 animals/salinity/diet). The temperature was $28.5^{\circ} \mathrm{C}$.

\section{Statistical tests}

The size and the survival were analysed using variance data. The resistance to the salinity shock was analysed using $\chi^{2}$ test.

\section{RESULTS}

\section{Immunological characterization}

hGH-like peptides were found in the larvae of Penaeus indicus at different stages. A good parallelism between the dilution sample curves and the $\mathrm{hGH}$ standard curve was observed (fig. 1).

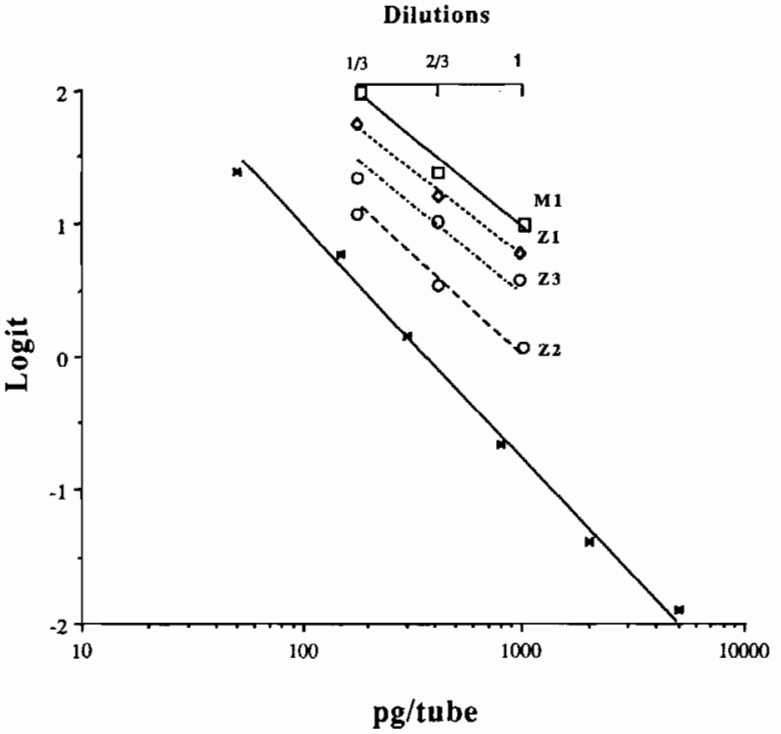

Figure 1. - Increasing dilution effect of hGH and extracts of different larval stages of $P$. indicus on the binding of $\left({ }^{125} \mathrm{I}\right) \mathrm{hGH}$ to the antibody.

\section{Estimation of the Penaeus hGH-like molecular weight}

This estimation was obtained with molecular sieving of larval extract of $P$. indicus $\left(\mathrm{M}_{3}\right)$ and radioimmunoassay of the fractions. The sample exhibited two

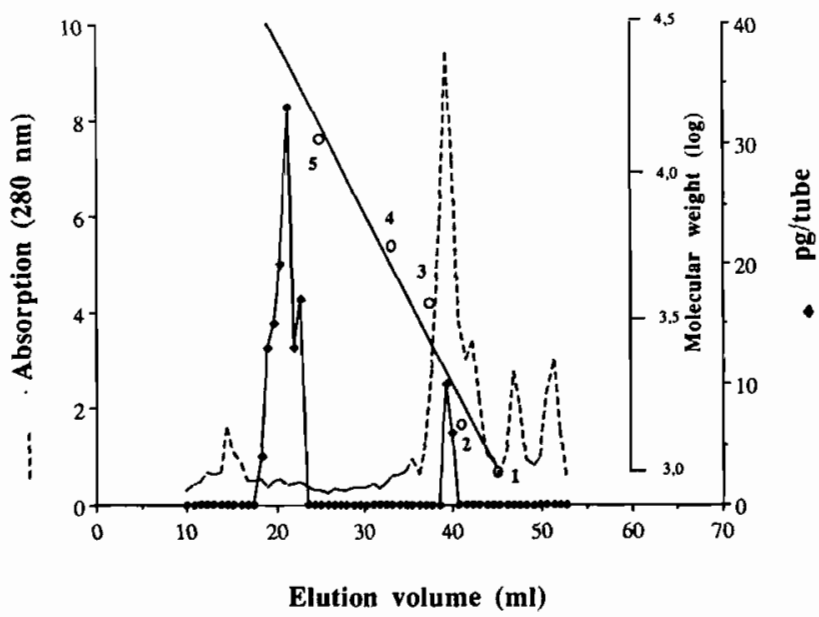

Figure 2. - Molecular sieving on G50 SF Sephadex column of immunoreactive hGH peptides extracted from $P$. indicus Mysis 1 larvae. Column was calibrated with: 1. RPCH (1 000 Da); 2. bacitracin (1 $411 \mathrm{Da}) ; 3$. glucagon $(3550) ; 4$. insulin $(5700 \mathrm{Da})$; 5. RNase (13000 Da)

peaks (fig. 2). The first elution, volume about $20 \mathrm{ml}$, corresponded to a molecular weight about 25000 daltons. The smaller one characterized a smaller peptide about 2000 daltons. 
Quantitatize zariations with larzal stages

Assays were realized on 7 successive larval stages, from $Z_{\text {Zoea }}\left(Z_{1}\right)$ to post-larvae $(P L)$, of the three species. Figure 3 shows fluctuations of the quantities of hGH-like peptides during the larval development. The values increased during the first stages and reach a maximum around the Mysis stages. Then, a break is observed with significant decrease of hGH-like level. The results expressed in pg peptide per $\mu \mathrm{g}$ total protein for P. stylirostris and $P$. vannamei are shown in figure 4 . The profiles were similar.

\section{hGH effect on larval development}

\section{- Survival}

The survival rates estimated by the ratio $P_{5} / Z_{1} \times 100$ did not vary significantly around $50 \%$ with the different diets.

\section{- Size}

The values of table 1 studied using variance data show that the effect of human growth hormone on the size was significant $(p<0.05)$. The mean study showed an increase of $6.6 \%$ in comparison with the diet 1 and $4.5 \%$ with the diet 2 in the whole stages. Yet, the real effect starts at the stage $\mathrm{M}_{3}$. Then, the increase was $13 \%$ at stage $P_{5}$ for diet 3 and $3 \%$ for diet 2 in comparison with diet 1 as control.

- Resistance to salinity variation of Penaeus vannamei larvae

The post-larvae which were fed with diet 3 seemed more resistant $(p<0.05$ at $25 \%, 20 \%, 15 \%$; no test was done for the salinities $25 \%$ and $10 \%$ o than the others to the hypo-osmotic shock (table 2).

\section{CONCLUSION}

These results showed that hGH-like immunoreactivity was found in Penaeids. The molecular sieving of an extract of Penaeus indicus larvae on column of Sephadex showed two peaks of immunoreactivity with molecular weights of about $25 \mathrm{kDa}$ and $2 \mathrm{kDa}$ (fig. 2). Such a distribution raises the problem of the origin and the biological activity of these two forms. Thus, $2 \mathrm{kDa}$ could be the result of the $25 \mathrm{kDa}$ degradation or another molecule with common epitopes with hGH. However, the molecular weight estimated by gel filtration is very close to that of vertebrate $\mathrm{GH}$ $(\sim 22 \mathrm{kDa})$. The dilution curves permitted a better identification of the immunoreactive molecule and an estimation of the non-specific interactions with the antiserum. The good parallelism between the hGH curve and the dilution curves ( $f$ ig. 1 ) gives some argument for the existence of a similarity of structure, at least at the antigenic site. These results are comparable with those obtained with other invertebrates (Patton and Kuo, 1977; Veenstra et al., 1985; Verhaert et al., 1986 with insects). It seems that in abalone (Moriyama et al. (1989)) two immunoreactive molecules with a molecular weight around $22 \mathrm{kDa}$ and $30 \mathrm{kDa}$ were found using antibody against salmon GH. All these results suggest the occurrence of molecules immunologically and structurally related to $\mathrm{GH}$ of vertebrates in animals even so phylogenetically distant.

Then, the question was: is the function conserved? Two different ways were explored: the variations in the immunoreactive peptides with physiological parameters involved in development and the in rivo efrect of dietary vertebrate GH on Penacids.

The role of hGH-like materiel in growth was already suggested in Palaemon serratus (Toullec and Van Wormhoudt, 1987) where significant variations of hGH-like peptides were measured during the intermolt cycle. It seems that they are also involved in larval development of Penaeus indicus, P. stylirostris and $P$. zanname $i$ as the quantitalive variations showed (fig. 3).

The amounts of hGH-like peptides increased with the stages to a break point at the $\mathrm{M}_{3}$ stages or postlarval stages. The low values observed in the first stages confirm the observations realized on $P$. serratus where no immunoreactivity was obtained during the ovogenesis and embryogenesis, but appeared with the first larval stages (Toullec, 1989). The break could be explained by a mistake in the counting of the larvae but the immunoreactivity related to the protein quantity gave the same profile for $P$. vannamei and $P$. stylirostris (fig. 4). The decrease of the amounts of protein in the last stages could be explained by a metabolic weakness, but it would be surprising that the three groups were unproductive. It is interesting to note that a similar decrease of digestive enzyme activities was measured in Penaeid shrimps (Van Wormhoudt, 1982). The parallelism of these variations is not explained at the moment. A RIA realized on the in vivo experiment animals confirmed the variations of hGH-like amounts observed. Thus, this characteristic could correspond to a metabolic reality. The decrease of the quantities of hGH-like peptides could be natural and integrated in a natural cyclic phenomenon. We observed actually a small increase of the hGH-like peptide level in the post-larvae of $P$. indicus. The assays realized on adults confirm the maintenance of such molecules after larval development. If these first results do not permit any definitive conclusions about the hGH-like nature and its role on the development and on the growth, the observed variations are a necessary condition to expect such an biological activity. Then, new experiments are needed to confirm the nature and the role of the molecule on development and growth.

In Haliotis (gastropod) the protein homologous to salmon GH was purified and stimulated growth by injection at physiological concentration (Kawauchi, pers. com.). The purpose of the experiment was to show a possible dietary effect of a vertebrate $\mathrm{GH}$ (the 
Table 1. - hGH effect on the size of larvae and post-larvae of $P$. vannamei. Selection of samples of size measured from the base of the rostrum to the extremity of the telson (SE: standard error).

\begin{tabular}{|c|c|c|c|c|c|c|}
\hline \multicolumn{3}{|c|}{ Diet 1} & \multicolumn{4}{|c|}{ Larval stages : Sizes in $\mathrm{mm}$} \\
\hline \multicolumn{2}{|c|}{ Zoea 2} & 7oea 3 & Mysis 2 & Mysis 3 & $\begin{array}{c}\text { Post } \\
1\end{array}$ & 5 \\
\hline \multicolumn{2}{|c|}{$\begin{array}{l}1.36 \\
1.32 \\
1.28 \\
1.28 \\
1.36 \\
1.32 \\
1.21 \\
1.46 \\
1.32 \\
1.36\end{array}$} & $\begin{array}{l}2.16 \\
2.36 \\
2.19 \\
2.29 \\
2.01 \\
2.08 \\
2.08 \\
2.01 \\
2.29 \\
2.19\end{array}$ & $\begin{array}{l}3.54 \\
3.51 \\
3.68 \\
3.09 \\
2.99 \\
3.05 \\
3.54 \\
3.51 \\
2.99 \\
3.16\end{array}$ & $\begin{array}{l}3.58 \\
3.58 \\
4.28 \\
3.54 \\
4.45 \\
3.86 \\
4.41 \\
4.31 \\
4.03 \\
4.13\end{array}$ & $\begin{array}{l}4.46 \\
4.71 \\
4.84 \\
4.92 \\
4.56 \\
4.50 \\
4.64 \\
4.32 \\
4.84 \\
5.20\end{array}$ & $\begin{array}{l}4.87 \\
5.70 \\
4.45 \\
4.72 \\
4.31 \\
5.56 \\
3.82 \\
4.80 \\
4.17 \\
4.80\end{array}$ \\
\hline $\begin{array}{c}\text { Mean } \\
\pm \\
\text { SE }\end{array}$ & $\begin{array}{l}1.32 \\
\pm \\
0.05\end{array}$ & $\begin{array}{l}2.16 \\
\pm \\
0.11\end{array}$ & $\begin{array}{l}3.31 \\
\pm \\
0.25\end{array}$ & $\begin{array}{l}4.02 \\
\pm \\
0.33\end{array}$ & $\begin{array}{l}4.70 \\
\pm \\
0.24\end{array}$ & $\begin{array}{l}4.72 \\
\pm \\
0.55\end{array}$ \\
\hline \multicolumn{7}{|c|}{ Diet 2} \\
\hline \multicolumn{2}{|c|}{$\begin{array}{l}1.32 \\
1.28 \\
1.36 \\
1.28 \\
1.49 \\
1.25 \\
1.36 \\
1.32 \\
1.36 \\
1.39\end{array}$} & $\begin{array}{l}2.01 \\
1.94 \\
2.05 \\
2.08 \\
2.05 \\
2.01 \\
2.08 \\
2.12 \\
2.12 \\
2.08\end{array}$ & $\begin{array}{l}3.40 \\
3.58 \\
3.54 \\
3.16 \\
3.40 \\
3.51 \\
3.40 \\
3.23 \\
3.68 \\
3.51\end{array}$ & $\begin{array}{l}3.79 \\
3.68 \\
4.38 \\
4.10 \\
4.45 \\
3.82 \\
4.10 \\
4.17 \\
438 \\
4.41\end{array}$ & $\begin{array}{l}5.16 \\
4.56 \\
4.60 \\
4.68 \\
4.50 \\
5.20 \\
4.71 \\
4.92 \\
4.81 \\
5.12\end{array}$ & $\begin{array}{l}4.87 \\
3.89 \\
4.66 \\
5.42 \\
4.38 \\
4.66 \\
5.14 \\
5.28 \\
5.42 \\
4.87\end{array}$ \\
\hline $\begin{array}{l}\text { Mean } \\
\pm \\
\text { SE }\end{array}$ & $\begin{array}{l}1.34 \\
\pm \\
0.06\end{array}$ & $\begin{array}{l}2.06 \\
\pm \\
0.04\end{array}$ & $\begin{array}{l}3.44 \\
\pm \\
0.15\end{array}$ & $\begin{array}{l}4.13 \\
\pm \\
0.27\end{array}$ & $\begin{array}{l}4.83 \\
\pm \\
0.24\end{array}$ & $\begin{array}{l}4.86 \\
\pm \\
0.46\end{array}$ \\
\hline \multicolumn{7}{|c|}{ Diet 3} \\
\hline \multicolumn{2}{|c|}{$\begin{array}{l}1.25 \\
1.36 \\
1.18 \\
1.25 \\
1.28 \\
1.25 \\
1.25 \\
1.28 \\
1.32 \\
1.28\end{array}$} & $\begin{array}{l}2.08 \\
2.12 \\
1.98 \\
2.12 \\
2.05 \\
2.12 \\
2.08 \\
2.05 \\
2.16 \\
2.16\end{array}$ & $\begin{array}{l}3.16 \\
3.05 \\
3.33 \\
3.44 \\
3.16 \\
3.68 \\
3.47 \\
3.54 \\
3.05 \\
3.51\end{array}$ & $\begin{array}{l}3.86 \\
4.62 \\
4.80 \\
4.45 \\
4.48 \\
4.62 \\
4.69 \\
4.56 \\
4.80 \\
4.62\end{array}$ & $\begin{array}{l}4.68 \\
4.92 \\
5.05 \\
5.23 \\
5.02 \\
4.64 \\
4.88 \\
5.20 \\
4.99 \\
5.16\end{array}$ & $\begin{array}{l}5.36 \\
5.98 \\
5.28 \\
5.56 \\
5.63 \\
5.21 \\
4.93 \\
5.56 \\
4.72 \\
5.08\end{array}$ \\
\hline $\begin{array}{l}\text { Mean } \\
\pm \\
\text { SE }\end{array}$ & $\begin{array}{l}1.27 \\
\pm \\
0.04\end{array}$ & $\begin{array}{l}2.09 \\
\pm \\
0.04\end{array}$ & $\begin{array}{l}3.34 \\
\pm \\
0.20\end{array}$ & $\begin{array}{l}4.55 \\
\pm \\
0.25\end{array}$ & $\begin{array}{l}5.16 \\
\pm \\
0.19\end{array}$ & $\begin{array}{l}5.33 \\
\pm \\
0.35\end{array}$ \\
\hline
\end{tabular}

Table 2. - Resistance tests to salinity shocks $(\%)$ to estimate the quality of post-larvae fed with different diets. The values are expressed in percentage of survival.

\begin{tabular}{lccccc}
\hline & \multicolumn{5}{c}{ Salinity } \\
\cline { 2 - 6 } & $35 \%$ & $25 \%$ & $15 \%$ & $10 \%$ \\
\hline Diet 1 & $100-100$ & $85.4-83.0$ & $38.5-4.20$ & $3.2-2.5$ & $0-0$ \\
Diet 2 & $100-100$ & $80.3-83.6$ & $43.4-54.2$ & $4.1-7.5$ & $0-0$ \\
Diet 3 & $100-100$ & $100-100$ & $58.8-66.3$ & $10-19.1$ & $0-0$ \\
\hline
\end{tabular}

hGH-like peptide being not purified) on the development of Penaeid shrimps. This technique for administration should be more practical in shrimp rearing.
Similar experiments have been realized with fishes like Thunnus thynnus. When purified specific GH was added to the diet, growth rates three times higher 

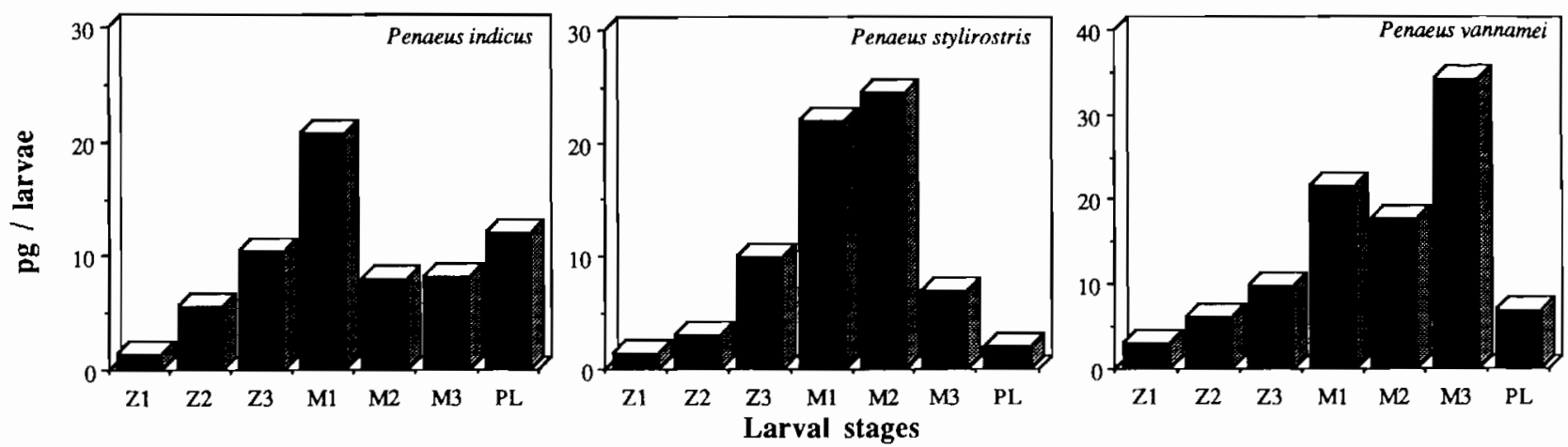

Figure 3. - Quantitative variations of hGH-like with larval stages in threc Penaeid species: $P$. indicus, P. stylirostris and $P$. vannamei.
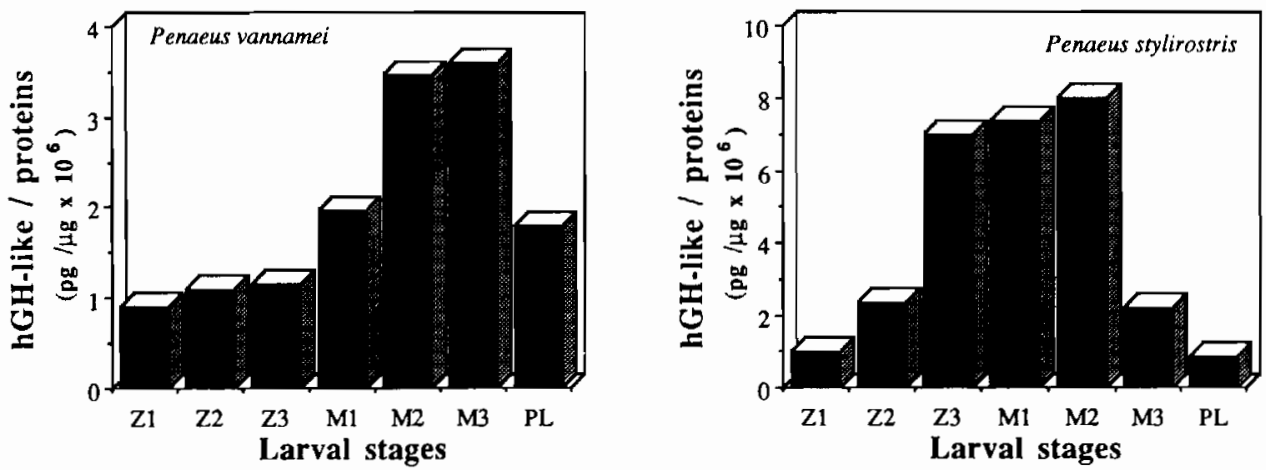

Figure 4. - Quantitative variations of hGH-like related to protein quantities with larval stages in two Penaeid species: P. stylirostris and P. vannamei.

were observed (Fishing Society Taiyo Gyogyo in collaboration with Kitasato University; Nikkei Sangyo Shinbun, April 14th 1987).

Our results obtained with $P$. vannamei showed the existence of a positive effect on the size of the larvae. It is necessary to be cautious about the results because of the measuring technique. The measurement of the animals from the rostral base to telson extremity does not directly measure the abdomen length. The measure of the cephalothoracic length would be more reliable. However, the measures per stage seem homogeneous and the standard deviation is the smallest in the diet 3 . That gives some assurance that these results are exploitable. They would confirm the work realized by Charmantier et al. (1989) on lobster larvae. In latter work, the hGH was injected into the animals but the addition of hGH to the diet seemed more suitable for the rearing. These results also suggest, like in fishes, that a mechanism should exist for the uptake of intact protein molecules (Moriyama et al., 1990). This hypothesis has to be tested.
The resistance test to salinity shocks gives some information about the quality of the different larvae. In Ecuador, the post-larvae from the natural medium stand up to a salinity of $0 \%$ for a few minutes. This resistance may be related to the quality of the larvae and the metabolic health. The fact that the animals fed with the hGH diet were more resistant may be considered as a positive result which is fully supporting those obtained before.

The existence of hGH-like peptides with a similar molecular weight and structure (at least the antigenic structure) together with the positive effect of the vertebrate hormone on crustaceans (Homarus, Charmantier et al., 1989 and Penaeus) give some encouraging information on the way of a relative conservation of the structure and the function of the GH. To remove all incertitudes and confirm the activity of hGHlike peptides on growth, it is necessary to purify the immunoreactive peptide to obtain its sequence and determine its role in vivo or in vitro. The use of such a specific molecule could notably improve the growth of shrimps and then the productivity of shrimp farms. 
Acknowledgements

This work was supported by a grant from the IFREMER to J. Y. Toullec. We thank Pr. R. Lafont for critical reviews.

\section{REFERENCES}

AQUACOP, 1982. Penaeid larval rearing in the Centre Océanographique du Pacifique. In: Handbook of Mariculture, Vol. 1, Crustacean Aquaculture, J. M. Mc Vey, C.R.C. Press, Ink. Boca Raton, Florida, 123-127.

Arlot-Bonnemains Y., A. Van Wormhoudt, P. Favrel, M. Foucheron-Peron, G. Milhaud, M.S. Moukhtar, 1986. Calcitonin-like peptides in the shrimp Palaemon serratus (Crustacea, Decapoda) during the intermold cycle. Experientia, 42, 419-420.

Arpagaus M., 1987. Vertcbrate insulin induces diapause termination in Pieris brassicae pupae. Roux's Arch. Dev. Biol., 196, 527-530.

Assaka L., C. R. Marchand, M. T. Strosser, A. Van Dorsselaer, 1987. Detection of somatostatin-14 peptide in the hepatopancreas of the snail Helix aspersa. C.R. Soc. Biol., 18, 213-221.

Berelowitz M. D., D. Le Roith, H. Von Schenk, C. Newgard, M. Szaba, L. A. Frohman, J. Shiloach, J. Roth, 1982. Somatostatin-like immunoreactivity and biological activity is present in Tetrahymena pyriformis, a ciliated protozoan. Endocrinology, 110, 1939-1944.

Charmantier G., M. Charmantier-Daures, D. E. Aiken, 1989. La somatotropine stimule la croissance de jeunes homards américains, Homarus americanus (Crustacea, Decapoda). C.R. Acad. Sci., Paris, 308, 21-26.

Duve H., A. Thorpe, N. R. Lazarus, 1979. Isolation of materiel displaying insulin-like immunological and biological activity from the brain of the blowfly Calliphora vomitoria. Biochem. J., 184, 221-227.

Falkmer S., R. P. Elde, C. Hellenström, B. Petersson, S. Efendic, J. Fohlman, J. B. Siljevall, 1977. Some phylogenetical aspects on the occurrence of somatostatin in the gastro-entero-pancreatic endocrine system. A histological and immunocytochemical study, combined with quantitative radioimmunological assays of tissue extracts. Arch. Histol. Jap., 40, Suppl. 99-117.

Favrel P., A. Van Wormhoudt, J. M. Studler, C. Bellon, 1987. Immunological and biological characterization of gastrin/cholescystokinin-like peptides in Palaemon serratus (Crustacea, Decapoda). Intermolt variations. Gen. Comp. Endocrinol., 65, 363-372.

Feurle G. E., H. Bodenmuller, I. Baca, 1983. The neuropeptide head activator stimulates amylase release from the rat pancreas in vitro. Neurosci. Lett., 38, 287-289.

Fritsch H. A. R., S. Van Norden, A. G. E. Pearse, 1982. Gastrointestinal and neurohormonal peptides in the alimentary tract and cerebral complex of Ciona intestinalis: their relevance to the evolution of the diffuse neuroendocrine system. Cell Tissue Res., 223, 369-402.

Fouchereau-Peron M., Y. Arlot-Bonnemains, G. Milhaud, M. S. Moukhtar, 1987. Immunoreactive salmon calcitonin-like molecule in crustaceans: high concentrations in
Nephrops norvegicus. Gen. Comp. Endocrinol., 65, 179. 183.

Grimm-J $\phi$ rgensen Y., $1983 a$. Possible physiological roles of thyrotropin releasing hormone and a somatostatin-like peptide in gastropods. Proceedings of the International Minisymposium Molluscan Endocrinology, Amstcrdam, Aug. 1982; J. Lever, H. Boer eds.

Grimm-J $\phi$ rgensen Y., 1983 b. Immunoreactive somatostatin in two pumonate gastropods. Gen. Comp. Endocrinol., 49, 108-114.

Kawauchi H., 1986. Biofutur, 69.

Le Roith D., J. Shiloach, J. Roth, H. Lesniak, 1980. Evolutionary origins of vertebrate hormones: substances similar to mammalian insulins are native to unicellular eucaryotes. Proc. Natl. Acad. Sci. USA, 77, 6184-6188.

Le Roith D., J. Shiloach, J. Roth, H. Lesniak, 1981. Insulin or a closely related molecule is native to Escherichia coli. J. Biol. Chem., 256, 6533-6536.

Le Roith D., A. S. Liotta, J. Roth, J. Shiloach, M. E. Lewis,

C. B. Pert, D. T. Krieger, 1982. Corticotropin and

B-endorphin-like material are native to unicellular organisms. Proc. Natl. Acad. Sci. USA, 79, 2086-2090.

Lowry O. M., N. Rosenbrough, A. Farr, R. Randall, 1951. Protein measurement with the folin phenol reagent. J. Biol. Chem., 193, 256-275.

Moreau R., C. Raoelison, B. J. Sutter, 1981. An intestinal insulin-like molecule in Apis mellifera (Hymenoptera). Comp. Biochem. Physiol., 69 A, 79-83.

Moriyama S., S. Atsuta, M. Kobayashi, H. Kawauchi, 1989. Growth hormone-like substance of abalone, Haliotis dissicus hannai. XIth International Symposium on Comparative Endocrinology, Malaga May 14-20, 1989.

Moriyama S., A. Takahashi, T. Hirano, H. Kawauchi, 1990. Salmon growth hormone is transported into the circulation of rainbow trout, Oncorhynchus mykiss after intestinal administration. J. Comp. Biochem., 160 B, 251257.

Morse D. E., 1984. Biochemical and genetic engineering for improved production of abalones and other valuable molluscs. Aquaculture, 39, 263-282.

Neushul P., 1985. Biofutur, 38.

Patton R. I., C. C. Kuo, 1977. The distribution of the STH-like protein in insects. Insect Biochem., 7, 487-489.

Plisetskaya E., V. K. Kazakov, L. Soltitskaya, L. G. Leibson, 1978. Insulin producing cells in the gut of fresh water bivalve mollucs Anadonta cygnea and Uniopicotrum and the role of insulin in the regulation of their carbohydrate metabolism. Gen. Comp. Endocrinol., 35, 133-145.

Sanders B., 1983a. Insulin-like peptides in the lobster Homarus americanus. I. Insulin immunoreactivity. Gen. Comp. Endocrinol., 50, 305-311. 
Sanders B., 1983 b. Insulin-like peptides in the lobster Homarus americanus. II. Insulin-like biological activity. Gen. Comp. Endocrinol., 50, 374-377.

Sanders B., 1983c. Insulin-like peptides in the lobster Homarus americanus. III. No glucostatic role. Gen. Comp. Endocrinol., 50, 378-382.

Scalise F. W., B. A. Larson, S. R. Vigna, 1984. Localization of a peptide identified by antibodies to gastrin/CCK in the gut of a morphogenic peptide from hydra. Proc. Natl. Acad. Sci. USA, $72(11), 7000-7004$.

Schot L.P.C., H. H. Boer, D. F. Swaab, Van Noorden, 1981. Immunocytochemical demonstration of peptidergic neurons in the central nervous system of the pound snail Lymnea stagnalis with antisera raised to biologically active peptides of vertebrates. Cell Tissue Res., 216, 273. 291.

Tager H. S., J. Markese, K. J. Kramer, R. D. Speirs, C. N. Childs, 1976. Glucagon-like and insulin-like hormones of the insect neurosecretory system. Biochem. J., 15j, 515-520.

Toullec J. Y., A. Van Wormhoudt, 1987. Variations quantitatives durant le cycle d'intermue de peptides apparentés à l'hormonc de croissance humaine chez Palaemon serratus (Crustacea, Decapoda). C.R. Acad. Sci., Paris, 305, 265-269.
Toullec J. Y., 1989. Recherche de substances hormonales actives sur la croissance d'invertébrés marins d'intérêt aquacole. These Univ. Paris VI, $140 \mathrm{p}$.

Van Wormhoudt A., 1982. Comparaison de l'évolution et du controle de l'activité des amylases et de protéases au cours du développement larvaire et des premiers stades juvéniles chez. Palaemon serratus, Macrobrachium rosenbergii et Penaeus japonicus. Actes coll. CNEXO, Brest, 14, 231-248.

Van Herp F., C. Bellon-Humbert, 1982. Localisation immunocytochimique de substances apparentées à la ncurophysine et à la vasopressine dans le pédoncule oculaire de Palaemon serratus Pennant (Crustacé, Décapode, Natantia). C.R. Acud. Sci., Paris, 2;5, 97-102.

Vecnstra J. A., H. M. Romberg-Privee, H. Schooneveld, J. M. Polak, 1985. Immunocytochemical localization of peptidergic neurons and neurosecretory cells in the neuroendocrine system of the colorado potato beetle with antisera to vertebrate regulatory peptides. Histochemistry, 62, 9-18.

Verhaert P., H. Van Mellacrt, K. Swinnen, A. De Loof, 1986. Vertebrate somatotropin-like peptides in insects. Prog. Develop. Biol., part A, 359-364. 